\title{
The effect of dietary supplementation of natural antioxidants and coated calcium butyrate on carcass traits, serum biochemical parameters, lipid peroxidation in meat and intestinal histomorphology in broilers
}

\author{
Erinç GÜMÜŞS,a,®, Seher KÜÇÜKERSAN ${ }^{2, b}$, Alev Gürol BAYRAKTAROĞLU ${ }^{3, c}$, Tevhide SEL ${ }^{4, d}$ \\ ${ }^{1}$ Aksaray University, Eskil Vocational School, Aksaray; ${ }^{2}$ Ankara University, Faculty of Veterinary Medicine, Department of Animal \\ Nutrition and Nutritional Disease, Ankara; ${ }^{3}$ Ankara University, Faculty of Veterinary Medicine, Department of Histology and \\ Embryology, Ankara; ${ }^{4}$ Ankara University, Faculty of Veterinary Medicine, Department of Biochemistry, Ankara, Turkey. \\ aORCID: 0000-0002-6839-8428; ' $\mathrm{ORCID:} \mathrm{0000-0002-2882-9203;} \mathrm{'} \mathrm{ORCID}$ : 0000-0001-9248-8370;
} ${ }^{\mathrm{d} O R C I D: 0000-0002-9753-779 X}$

\author{
Corresponding author: erincgumus@aksaray.edu.tr \\ Received date: 27.01.2020 - Accepted date: 14.10.2020
}

\begin{abstract}
The aim of this study was to investigate the effects of vitamin E, grape seed extract and green tea extract with or without supplementation of coated calcium butyrate in broilers based on carcass traits, some biochemical parameters, intestinal histomorphology, and lipid peroxidation in meat. Two hundred fifty-two one-day-old broiler chicks were divided into nine groups, one control and eight experimental. Control group fed only a basal diet (control). The experimental groups' diets contained feed additives as; coated calcium butyrate (CCB), vitamin E (VitE), grape seed extract (GSE), green tea extract (GTE), a combination of vitamin E with coated calcium butyrate ( $\mathrm{VitE}+\mathrm{CCB})$, grape seed extract with coated calcium butyrate (GSE+CCB), green tea extract with coated calcium butyrate $(\mathrm{GTE}+\mathrm{CCB})$, and a combination of grape seed extract, green tea extract, and coated calcium butyrate (GSE+GTE+CCB) respectively. According to the study results; no significant differences were observed in gut histomorphology and serum biochemical parameters. The broilers fed with GSE and GTE with/without CCB had significantly higher hot carcass yield than control, VitE, and VitE+CCB. Furthermore, all groups showed significantly lesser lipid peroxidation in meat than control; however, the VitE group had the lowest malondialdehyde (MDA) levels. It can be concluded that the combination of CCB with natural antioxidants could be used to improve carcass traits and meat antioxidant capacity in broilers.
\end{abstract}

Keywords: Broiler, coated calcium butyrate, intestinal histomorphology, lipid peroxidation, natural antioxidants.

\section{Etçi piliç rasyonlarına doğal antioksidanlar ve kaplanmış kalsiyum bütirat ilavesinin karkas özellikleri, serum biyokimyasal parametreleri, ette lipid peroksidasyon ve bağırsak histomorfolojisi üzerine etkileri}

Özet: Bu çalışmanın amacı, vitamin E, üzüm çekirdeği ekstraktı ve yeşil çay ekstraktının tek başına veya kaplanmış kalsiyum bütirat ile birlikte kullanılmasının etçi piliçlerde karkas özellikleri, bazı biyokimyasal parametreleri, bağırsak histomorfolojisi ve ette lipid peroksidasyon düzeyi üzerindeki etkisini araştırmaktır. Bir günlük 252 civciv, bir kontrol ve sekiz deneme grubu olmak üzere dokuz gruba ayrılmıştır. Kontrol grubuna sadece temel rasyon verilmiştir (Kontrol). Deneme gruplarının yemleri sırasıyla kaplanmış kalsiyum bütirat (CCB), vitamin E (VitE), üzüm çekirdeği ekstraktı (GSE), yeşil çay ekstraktı (GTE), vitamin E ile kaplanmış kalsiyum bütirat (VitE+CCB), üzüm çekirdeği ekstraktı ile kaplanmış kalsiyum bütirat (GSE+CCB), yeşil çay ekstraktı ile kaplanmış kalsiyum bütirat $(\mathrm{GTE}+\mathrm{CCB})$ ve üzüm çekirdeği + kaplanmış kalsiyum bütirat + yeşil çay ekstraktının (GSE+GTE+CCB) birlikte olduğu yem katkılarını içermektedir. Çalışma sonuçlarına göre; bağırsak histomorfolojisi ve serum biyokimyasal parametreler açısından gruplar arasında anlamlı bir fark tespit edilememiştir. GSE ve GTE tek başına veya CCB ile verildiği etçi piliçlerde, Kontrol, VitE ve VitE+CCB kombinasyonu verilen gruplara göre sıcak karkas randımanın anlamlı derecede yüksek olduğu gözlenmiştir. Ayrıca, bütün gruplar kontrol grubuna göre ette önemli düzeyde daha düşük lipid peroksidasyonu gösterdi, fakat VitE grubu en düşük MDA seviyesine sahipti. Sonuç olarak etçi piliçlerde CCB'nin doğal antioksidanlarla kombine olarak kullanılmasının karkas özellikleri ve et antioksidan kapasitesini iyileştirmek için kullanılabileceği sonucuna varılabilmektedir.

Anahtar sözcükler: Bağırsak histomorfolojisi, doğal antioksidanlar, etlik piliç, kaplanmış kalsiyum bütirat, lipid peroksidasyon. 


\section{Introduction}

Oxidation is a natural part of the metabolism's biological activity, yet a high intake of poly-unsaturated fatty acids (PUFA), oxidized lipids, or ingesting an insufficient amount of nutrients essential for the antioxidant defense system could cause excessive level of lipid peroxidation $(16,29)$. The commonly used energy and protein sources in poultry diets, such as fishmeal and vegetable oils, are rich with PUFA. They also increase susceptibility to lipid peroxidation and account for the loss in the nutritional value and shelf life of poultry meat and meat products $(29,35)$. These kind of unwanted side effects could be reduced with antioxidant supplementation in poultry nutrition (15).

Although synthetic antioxidants are commonly used in animal nutrition due to their effectiveness and low cost, more attention is being given to natural antioxidants due to increasing consumer concerns (7). Similarly, the broiler industry has been investigating new sources of natural antioxidants to establish antioxidant stability in meat tissues $(29,35)$. Most natural antioxidants consist of lipid soluble phenolics, such as tocopherols or phenolic extracts prepared from plants like rosemary, sage, green tea, grape seed, and oregano (35). Green tea and grape by-products or extracts are two of the most important polyphenol-rich sources due to their mass production, easy accessibility, and ability to capture free radicals $(26,33)$.

Protecting the intestinal health of poultry is critical in order to reach target body weight gain and feed conversion ratio $(3,36)$. Butyric acid, one of the shortchain fatty acids, has been shown to have a significant effect on the proliferation, growth, and differentiation of intestinal mucosa cells by means of its influence on gene expression and protein synthesis (10). Salt forms of butyric acid are preferred in animal nutrition due to the butyric acid's strong unpleasant odor (10). Salt forms of butyric acid also significantly improve the intestinal histomorphology of broilers in different phases of growth $(3,10,22)$. Due to the fact that non-protected butyrate salts are mostly absorbed in the upper part of the gastrointestinal tract, microencapsulation is used to protect butyrate salts until they reach the broiler intestines (31).

The aim of this study was to investigate the effects of alone and combined dietary use of coated calcium butyrate $(\mathrm{CCB})$ with three important natural antioxidants; vitamin $\mathrm{E}$ (VitE), grape seed extract (GSE), and green tea extract (GTE) based on carcass traits, serum biochemical parameters, intestinal histomorphology, and muscular antioxidant activity in broilers.

\section{Material and Method}

Bird Husbandry and Diets: This research was conducted in the Ankara University Veterinary Faculty
Research and Application Farm and approved by the Ankara University Ethics Committee (decision no. 201518-201). The feeding trial was carried out on 252 male Ross 308 broiler chicks (initial weight $43.66 \pm 0.05 \mathrm{~g}$ ) assigned to nine groups. Every treatment group consisted of four replicates of seven chicks each. All chickens were placed in wired cages and were held in an environmentally controlled room. The temperature of the environment was kept at $32^{\circ} \mathrm{C}( \pm 1)$ for the first week and then decreased to $25^{\circ} \mathrm{C}$ the days after. Feed and water were offered ad libitum to the chickens. Basal diets were formulated for starter (1-14 days) and finisher (15-41 days) periods. The diets were produced in a local feed mill, based on corn and soybeans, and formulated to be isocaloric and isonitrogenous for starter and finisher periods in order to meet all nutritional requirements (23). The ingredients and calculated chemical composition of the basal diet are shown in Table 1. All diets were supplemented with 250 $\mathrm{mg} / \mathrm{kg}$ CCB, except for the control group. The CCB used in the study was a commercial product consisting of 860 $\mathrm{g} / \mathrm{kg}$ salt ( $160 \mathrm{~g} \mathrm{Ca}$ and $700 \mathrm{~g}$ butyric acid) and coated with a matrix of vegetable oils (Globamax B700, Sanita Sağlık Ürünleri A.Ş.). In order to better understand the effect of the natural antioxidants in the diet, no antioxidant other than $45 \mathrm{mg}$ vitamin E, $70 \mathrm{mg}$ zinc, and $0.3 \mathrm{mg}$ selenium per $\mathrm{kg}$ in the vitamin and mineral premix was used in the study.

The control group was fed only with basal diet (Control). The experimental diets were supplemented with CCB, VitE, GSE, GTE and a combination of CCB and natural antioxidants: $\mathrm{VitE}+\mathrm{CCB}, \mathrm{GSE}+\mathrm{CCB}, \mathrm{GTE}+\mathrm{CCB}$, and GSE+GTE+CCB mixture, respectively. The VitE (Vimar Gıda Tarım Hayvancılık A.Ş., İstanbul, Turkey), GSE (Nor-Grape, Vimar Gıda Tarım Hayvancılık A.Ş., İstanbul, Turkey), and GTE (Balen, Arı Mühendislik Ltd. Şti, Ankara, Turkey) were procured from commercial products. The polyphenols and alpha-tocopherol were added as $200 \mathrm{mg} / \mathrm{kg}$, as described by Vossen et al. (35) and the CCB was added $250 \mathrm{mg} / \mathrm{kg}$ into the diet, based on the study of Van Den Borne et al. (31).

Traits measured: Twelve broilers were selected, weighed, and slaughtered from each group on the day 41 of the experiment. Afterward, blood samples were taken from the jugular vein and were centrifuged to collect serum. The carcasses were weighed to calculate hot carcass yield. The heart, spleen, liver, abdominal fat, gizzard, proventriculus, and bursa of Fabricius were also weighed. Their relative weights of them were calculated by dividing into slaughtering weight. Breast meat samples were taken from the hot carcasses of broilers. The serum and breast meat samples were stored at $-20^{\circ} \mathrm{C}$ until the time the analyses were carried out.

The serum samples were analyzed for levels of alkaline phosphatase (ALP), alanine amino transferase 
(ALT), aspartate amino transferase (AST), total cholesterol, triglyceride, high-density lipoprotein (HDL), and low-density lipoprotein (LDL) by an automatic analyzer (BT 3000, Biotechnica Instruments, Italy) with commercial kits (Randox RX series, Randox Laboratories Ltd., London, United Kingdom).

A 25-mg of breast meat from each animal was mixed with a 250- $\mu$ RIPA buffer and sonicated (Bandelin Sonoplus HD 3100 Homogeniser). The blend was centrifuged at $1.600 \times \mathrm{g}$ for four minutes at $4^{\circ} \mathrm{C}$, and supernatants were taken to determine the malondialdehyde (MDA) levels. The SpectraMax ${ }^{\circledR} \mathrm{i} 3$ Plate Reader (Molecular Devices, Sunnyvale, CA, USA) was used to measure the absorbance at $540 \mathrm{~nm}$ with TBARS Assay Kits (Molecular Devices, Sunnyvale, CA, USA).

The small intestine tissue samples were taken from the jejunum and ileum according to the method described by Calik et. al (8). The samples were fixed in a $10 \%$ neutral buffered formalin for $24 \mathrm{~h}$. Thereafter, following routine histological process, samples were embedded in paraffin and then stained with Mallory's modified triple stain in order to visualize general morphology (5). The histological sections were examined under a light microscope (Leica DM 2500, Leica Microsystems GmbH, Wetzlar, Germany) and captured with the Leica DFC450 (Leica Microsystems, Heerbrugg, Germany) digital microscope camera. Morphometric indices were evaluated using the ImageJ software (Image J, US National Institutes of Health, Bethesda, MD, USA) as described by Calik et. al (8).

Statistical analysis: All received data were analyzed by the one-way analysis of variance (ANOVA) procedure of the SPSS version 20 (Inc., Chicago IL, USA) (12). The differences among the groups were examined with a posthoc Tukey test. Any statistical differences were considered significant at $\mathrm{P}<0.05$.

Table 1. The ingredients and chemical composition of the basal diets (as-fed basis).

\begin{tabular}{|c|c|c|}
\hline Ingredients (\%) & $\begin{array}{l}\text { Starter diet } \\
\text { (1-14 days) }\end{array}$ & $\begin{array}{l}\text { Finisher diet } \\
\text { (15-41 days) }\end{array}$ \\
\hline Corn & 46.59 & 51.86 \\
\hline Corn gluten meal & 2.55 & 3.60 \\
\hline Wheat & 5.00 & 10.00 \\
\hline Full fat soya & 0.00 & 4.50 \\
\hline Soybean meal & 37.50 & 23.50 \\
\hline Monocalcium phosphate & 0.99 & 0.66 \\
\hline Limestone & 1.89 & 1.27 \\
\hline Sodium butyrate & 0.30 & 0.08 \\
\hline Salt & 0.30 & 0.32 \\
\hline Soybean Oil & 4.00 & 3.50 \\
\hline Methionine & 0.30 & 0.22 \\
\hline Lysine & 0.24 & 0.23 \\
\hline Threonine & 0.12 & 0.07 \\
\hline Choline chloride (\%75) & 0.07 & 0.05 \\
\hline Vitamin-mineral mix* & 0.10 & 0.10 \\
\hline Enzyme (6-Phytase) & 0.05 & 0.05 \\
\hline Total & 100.00 & 100.00 \\
\hline \multicolumn{3}{|l|}{ Calculated composition } \\
\hline Crude Protein, $\%$ & 23.00 & 21.00 \\
\hline Ether extract, \% & 6.00 & 6.50 \\
\hline Crude Ash, $\%$ & 6.00 & 5.00 \\
\hline Crude fibre, $\%$ & 3.50 & 4.00 \\
\hline Sodium, $\%$ & 0.22 & 0.16 \\
\hline Calcium, \% & 1.10 & 0.90 \\
\hline Phosphorus, \% & 0.50 & 0.45 \\
\hline Total Lysine, $\%$ & 1.44 & 1.24 \\
\hline Total Met + Sis, $\%$ & 1.07 & 0.95 \\
\hline $\mathrm{ME}^{* *}(\mathrm{kcal} / \mathrm{kg})$ & 3,100 & 3,200 \\
\hline
\end{tabular}

* Vitamin - mineral mix supplied the following per kg of diet: Vitamin A 15000 IU. Vitamin D3 3000 IU. Vitamin E 45 mg, Manganese $100 \mathrm{mg}$, Iron $100 \mathrm{mg}$, Zinc $70 \mathrm{mg}$, Copper $15 \mathrm{mg}$, Iodine $1.5 \mathrm{mg}$, Cobalt $0.5 \mathrm{mg}$, Selenium $0.3 \mathrm{mg}$. ** Metabolizable energy content of diets was calculated according to the equation of Carpenter and Clegg (9) 


\section{Results}

The effect of natural antioxidants and CCB supplementation on the carcass yield and percentages of organs are shown in Table 2 . The carcass yield $(\mathrm{P}<0.001)$ and relative liver weight $(\mathrm{P}<0.05)$ was significantly affected by polyphenol supplementation with/without CCB. However, no significant interaction between the groups was found for the percentages of heart, spleen, bursa of Fabricius, gizzard, proventriculus and abdominal fat $(\mathrm{P}>0.05)$.

The serum biochemical analysis results showed that dietary supplement of natural antioxidants with or without CCB does not affect serum ALT, ALP, AST, total cholesterol, triglyceride, LDL, and HDL levels in broiler chickens at day 41 (Table 3) $(\mathrm{P}>0.05)$.

Table 2. The effects of natural antioxidant and coated calcium butyrate supplementation on carcass yield and relative weight percentages $(\mathrm{g} / 100 \mathrm{~g} \mathrm{BW})$ of internal organs.

\begin{tabular}{|c|c|c|c|c|c|c|c|c|c|}
\hline $\begin{array}{l}\text { Treat } \\
\text { ments }\end{array}$ & $\begin{array}{l}\text { Slaughter } \\
\text { weight }(g)\end{array}$ & $\begin{array}{c}\text { Hot } \\
\text { carcass } \\
\text { yield }(\%)\end{array}$ & $\begin{array}{c}\text { Heart } \\
(\%)\end{array}$ & $\begin{array}{c}\text { Spleen } \\
(\%)\end{array}$ & Liver (\%) & $\begin{array}{c}\text { Bursa of } \\
\text { Fabricius } \\
(\%)\end{array}$ & $\begin{array}{c}\text { Abdominal } \\
\text { fat }(\%)\end{array}$ & $\begin{array}{c}\text { Gizzard } \\
(\%)\end{array}$ & $\begin{array}{c}\text { Pro- } \\
\text { ventriculus } \\
(\%)\end{array}$ \\
\hline Control & $2332.75 \pm 97.72^{\mathrm{d}}$ & $69.85 \pm 0.51^{\mathrm{b}}$ & $0.40 \pm 0.04$ & $0.12 \pm 0.03$ & $2.09 \pm 0.05^{\mathrm{a}}$ & $0.18 \pm 0.01$ & $1.62 \pm 0.11$ & $1.21 \pm 0.13$ & $0.33 \pm 0.02$ \\
\hline $\mathrm{CCB}$ & $2404.92 \pm 69.83^{\mathrm{cd}}$ & $70.79 \pm 0.44^{\mathrm{ab}}$ & $0.38 \pm 0.04$ & $0.11 \pm 0.03$ & $1.99 \pm 0.06^{\mathrm{ab}}$ & $0.14 \pm 0.01$ & $1.59 \pm 0.09$ & $1.26 \pm 0.03$ & $0.29 \pm 0.01$ \\
\hline VitE & $2471.25 \pm 65.12^{\mathrm{abc}}$ & $70.58 \pm 0.49^{\mathrm{ab}}$ & $0.39 \pm 0.04$ & $0.11 \pm 0.02$ & $2.07 \pm 0.04^{\mathrm{a}}$ & $0.16 \pm 0.02$ & $1.64 \pm 0.11$ & $1.18 \pm 0.04$ & $0.29 \pm 0.01$ \\
\hline GSE & $2557.25 \pm 94.20^{\mathrm{a}}$ & $71.60 \pm 0.71^{\mathrm{a}}$ & $0.38 \pm 0.06$ & $0.12 \pm 0.04$ & $1.96 \pm 0.05^{\mathrm{ab}}$ & $0.14 \pm 0.01$ & $1.56 \pm 0.06$ & $1.20 \pm 0.04$ & $0.30 \pm 0.03$ \\
\hline GTE & $2528.58 \pm 74.56^{\mathrm{ab}}$ & $71.99 \pm 1.10^{\mathrm{a}}$ & $0.39 \pm 0.07$ & $0.11 \pm 0.02$ & $1.88 \pm 0.05^{\mathrm{b}}$ & $0.14 \pm 0.02$ & $1.51 \pm 0.13$ & $1.18 \pm 0.03$ & $0.29 \pm 0.04$ \\
\hline $\begin{array}{l}\text { VitE+ } \\
\text { CCB }\end{array}$ & $2458.50 \pm 61.80^{\mathrm{bc}}$ & $70.85 \pm 0.36^{\mathrm{ab}}$ & $0.38 \pm 0.04$ & $0.11 \pm 0.02$ & $1.94 \pm 0.06^{\mathrm{ab}}$ & $0.17 \pm 0.01$ & $1.57 \pm 0.10$ & $1.21 \pm 0.05$ & $0.31 \pm 0.01$ \\
\hline $\begin{array}{l}\text { GSE+ } \\
\text { CCB }\end{array}$ & $2559.58 \pm 36.67^{\mathrm{a}}$ & $71.59 \pm 0.54^{\mathrm{a}}$ & $0.38 \pm 0.07$ & $0.10 \pm 0.03$ & $1.89 \pm 0.06^{\mathrm{b}}$ & $0.13 \pm 0.02$ & $1.58 \pm 0.07$ & $1.21 \pm 0.06$ & $0.30 \pm 0.04$ \\
\hline $\begin{array}{l}\text { GTE+ } \\
\text { CCB }\end{array}$ & $2520.50 \pm 85.51^{\mathrm{ab}}$ & $71.59 \pm 0.36^{\mathrm{a}}$ & $0.39 \pm 0.07$ & $0.12 \pm 0.05$ & $1.86 \pm 0.04^{b}$ & $0.14 \pm 0.02$ & $1.54 \pm 0.10$ & $1.27 \pm 0.02$ & $0.31 \pm 0.05$ \\
\hline $\begin{array}{l}\text { GSE+ } \\
\text { GTE+ } \\
\text { CCB }\end{array}$ & $2479.17 \pm 73.38^{\mathrm{abc}}$ & $71.34 \pm 0.34^{\mathrm{a}}$ & $0.38 \pm 0.13$ & $0.11 \pm 0.05$ & $1.98 \pm 0.04^{\mathrm{ab}}$ & $0.16 \pm 0.01$ & $1.55 \pm 0.13$ & $1.34 \pm 0.05$ & $0.32 \pm 0.05$ \\
\hline $\mathrm{P}$ & $<0.001$ & $<0.001$ & 0.983 & 0.703 & 0.034 & 0.132 & 0.992 & 0.171 & 0.094 \\
\hline
\end{tabular}

a,b,c,d:Means within a column with different letters are significantly different $(\mathrm{P}<0.05)$. VitE, Vitamin E; CCB, Coated Calcium Butyrate; GSE, Grape Seed Extract; GTE, Green Tea Extract.

Table 3. The effects of natural antioxidants and coated calcium butyrate supplementation on some serum biochemical parameters.

\begin{tabular}{|c|c|c|c|c|c|c|c|}
\hline Treatments & $\begin{array}{c}\text { ALT } \\
\text { (IU/L) }\end{array}$ & $\begin{array}{c}\text { ALP } \\
\text { (IU/L) }\end{array}$ & $\begin{array}{c}\text { AST } \\
\text { (IU/L) }\end{array}$ & $\begin{array}{c}\text { Total } \\
\text { cholesterol } \\
(\mathrm{mg} / \mathrm{dL})\end{array}$ & $\begin{array}{l}\text { Triglyceride } \\
\quad(\mathrm{mg} / \mathrm{dL})\end{array}$ & $\underset{(\mathbf{m g} / \mathbf{d L})}{\mathbf{L D L}}$ & $\underset{(\mathbf{m g} / \mathbf{d L})}{\text { HDL }}$ \\
\hline Control & $3.36 \pm 0.74$ & $1934.55 \pm 269.08$ & $215.42 \pm 12.05$ & $111.10 \pm 3.66$ & $43.00 \pm 2.54$ & $26.87 \pm 5.73$ & $73.58 \pm 3.85$ \\
\hline $\mathrm{CCB}$ & $2.82 \pm 0.42$ & $1945.10 \pm 270.79$ & $216.91 \pm 17.51$ & $103.80 \pm 5.56$ & $43.38 \pm 6.57$ & $17.25 \pm 3.50$ & $67.33 \pm 3.65$ \\
\hline VitE & $3.63 \pm 0.73$ & $2063.20 \pm 270.79$ & $237.00 \pm 28.60$ & $107.13 \pm 6.80$ & $51.50 \pm 5.39$ & $23.45 \pm 6.69$ & $63.55 \pm 3.69$ \\
\hline GSE & $2.89 \pm 0.45$ & $1871.00 \pm 210.85$ & $240.00 \pm 25.25$ & $106.00 \pm 6.87$ & $48.90 \pm 4.63$ & $19.13 \pm 7.81$ & $63.18 \pm 3.85$ \\
\hline GTE & $3.13 \pm 0.73$ & $1739.78 \pm 213.76$ & $265.43 \pm 26.68$ & $107.13 \pm 9.22$ & $50.70 \pm 4.63$ & $20.71 \pm 9.20$ & $69.18 \pm 3.85$ \\
\hline $\mathrm{VitE}+\mathrm{CCB}$ & $2.78 \pm 0.40$ & $1827.08 \pm 134.38$ & $241.33 \pm 19.06$ & $101.36 \pm 6.80$ & $41.56 \pm 5.59$ & $27.63 \pm 3.87$ & $70.38 \pm 3.85$ \\
\hline $\mathrm{GSE}+\mathrm{CCB}$ & $2.22 \pm 0.40$ & $1708.63 \pm 191.01$ & $208.78 \pm 26.25$ & $98.00 \pm 4.10$ & $47.10 \pm 3.96$ & $14.62 \pm 2.63$ & $67.30 \pm 3.85$ \\
\hline $\mathrm{GTE}+\mathrm{CCB}$ & $2.58 \pm 0.53$ & $1960.25 \pm 161.60$ & $228.27 \pm 26.44$ & $103.00 \pm 5.87$ & $44.75 \pm 2.33$ & $18.52 \pm 4.31$ & $72.23 \pm 3.85$ \\
\hline $\begin{array}{c}\text { GSE+GTE+ } \\
\text { CCB }\end{array}$ & $2.30 \pm 0.42$ & $1845.88 \pm 108.84$ & $209.50 \pm 16.49$ & $100.20 \pm 6.23$ & $44.80 \pm 4.37$ & $17.38 \pm 6.52$ & $77.90 \pm 3.85$ \\
\hline $\mathrm{P}$ & 0.661 & 0.977 & 0.670 & 0.907 & 0.647 & 0.655 & 0.127 \\
\hline
\end{tabular}

VitE, Vitamin E; CCB, Coated Calcium Butyrate; GSE, Grape Seed Extract; GTE, Green Tea Extract. 
Table 4 illustrates the effects of natural antioxidant administration with or without CCB on villus height and crypt depth in the jejunum and ileum of broiler chickens at day 41. Ileum crypt depth decreased significantly in the groups fed with VitE, GSE, VitE+CCB, and GTE+CCB supplementation at the end of the study $(\mathrm{P}<0.05)$. Lowest values were recorded from the birds supplemented with GSE and VitE+CCB. There was no significant difference in jejunum villus height, jejunum crypt depth, jejunum villus height/crypt depth ratio, ileum villus height, and ileum villus height/crypt depth ratio between the control group and the experimental groups $(\mathrm{P}>0.05)$.

MDA concentrations in the breast meat of broiler chickens are presented in Figure 1. A positive improvement in MDA-reduced levels was examined in the broilers supplemented with natural antioxidants with or without CCB compared to the ones fed with basal diet $(\mathrm{P}<0.05)$. The best value was recorded from the group that received dietary VitE supplementation.

Table 4. The effects of natural antioxidant and coated calcium butyrate supplementation on the jejunum and ileum histomorphology of broiler chickens at day 41.

\begin{tabular}{ccccccc}
\hline \multirow{2}{*}{ Treatments } & \multicolumn{3}{c}{ Jejunum } & \multicolumn{2}{c}{ Ileum } \\
\cline { 2 - 7 } & $\begin{array}{c}\text { Villus height } \\
(\boldsymbol{\mu m})\end{array}$ & $\begin{array}{c}\text { Crypt depth } \\
(\boldsymbol{\mu m})\end{array}$ & $\begin{array}{c}\text { Villus height/ } \\
\text { crypt depth }\end{array}$ & $\begin{array}{c}\text { Villus height } \\
(\boldsymbol{\mu m})\end{array}$ & $\begin{array}{c}\text { Crypt depth } \\
(\boldsymbol{\mu m})\end{array}$ & $\begin{array}{c}\text { Villus height/ } \\
\text { crypt depth }\end{array}$ \\
\hline Control & $1127.30 \pm 97.93$ & $194.20 \pm 4.90$ & $5.82 \pm 0.52$ & $792.00 \pm 64.04$ & $176.77 \pm 7.99^{\mathrm{a}}$ & $4.46 \pm 0.25$ \\
CCB & $1153.27 \pm 36.77$ & $209.97 \pm 19.12$ & $5.62 \pm 0.39$ & $748.30 \pm 68.83$ & $175.80 \pm 9.39^{\mathrm{a}}$ & $4.30 \pm 0.36$ \\
VitE & $1187.60 \pm 101.89$ & $206.70 \pm 10.14$ & $5.72 \pm 0.41$ & $671.20 \pm 46.46$ & $161.90 \pm 4.78^{\mathrm{ab}}$ & $4.15 \pm 0.21$ \\
GSE & $1236.20 \pm 73.83$ & $222.20 \pm 2.69$ & $5.58 \pm 0.37$ & $685.00 \pm 59.72$ & $156.73 \pm 5.80^{\mathrm{b}}$ & $4.35 \pm 0.24$ \\
GTE & $1228.03 \pm 73.28$ & $213.90 \pm 8.86$ & $5.75 \pm 0.28$ & $782.2 \pm 29.37$ & $179.04 \pm 7.95^{\mathrm{a}}$ & $4.39 \pm 0.21$ \\
VitE+CCB & $1247.30 \pm 76.23$ & $205.50 \pm 5.45$ & $6.12 \pm 0.49$ & $631.70 \pm 36.07$ & $157.67 \pm 3.87^{\mathrm{b}}$ & $4.02 \pm 0.25$ \\
GSE+CCB & $1224.30 \pm 49.94$ & $224.80 \pm 10.25$ & $5.49 \pm 0.36$ & $788.00 \pm 39.08$ & $176.10 \pm 7.24^{\mathrm{a}}$ & $4.49 \pm 0.23$ \\
GTE+CCB & $1443.10 \pm 21.68$ & $227.53 \pm 5.84$ & $6.36 \pm 0.23$ & $771.60 \pm 17.82$ & $164.47 \pm 2.08^{\mathrm{ab}}$ & $4.69 \pm 0.12$ \\
GSE+GTE+CCB & $1350.10 \pm 35.97$ & $216.73 \pm 4.84$ & $6.25 \pm 0.25$ & $773.43 \pm 47.90$ & $179.80 \pm 4.48^{\mathrm{a}}$ & $4.29 \pm 0.21$ \\
P & 0.093 & 0.218 & 0.725 & 0.139 & 0.045 & 0.714 \\
\hline
\end{tabular}

a,b:Means within a column with different letters are significantly different $(\mathrm{P}<0.05)$. VitE, Vitamin E; CCB, Coated Calcium Butyrate; GSE, Grape Seed Extract; GTE, Green Tea Extract.

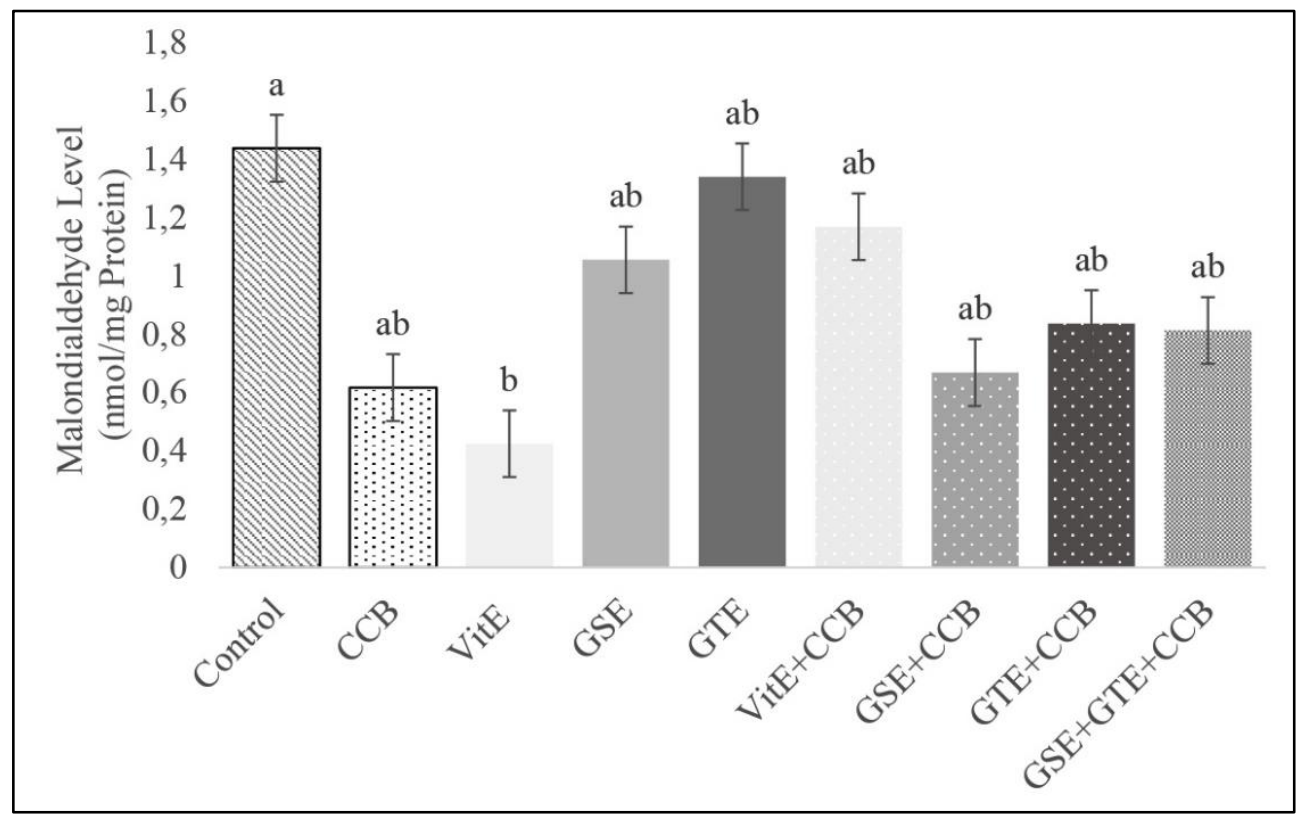

Figure 1. The effects of natural antioxidant and coated calcium butyrate supplementation on MDA levels on breast meat of broiler chickens at day 41 .

a,b: For each treatment, bars with different letters are significantly different $(\mathrm{P}<0.05)$. VitE, Vitamin E; CCB, Coated Calcium Butyrate; GSE, Grape Seed Extract; GTE, Green Tea Extract. 


\section{Discussion and Conclusion}

The experiment showed that both supplementation of CCB and natural antioxidants in broiler diets improved slaughter weight and carcass yield, compared to the control group. Especially, broilers fed with GSE and GSE+CCB supplementation showed the best slaughter weights. Similar results were found for the positive effect of dietary grape by-product supplementation on the final body weight of broilers (1) and rabbits (18). In addition, several studies also reported positive effect of VitE (26, $32), \operatorname{GTE}(6,26)$, and butyrate salts $(3,10,24)$ on the final body weight of broilers. The movement-retarding effects of tannins in intestines to improve nutrient absorption might be one possible reason for this result (1). Furthermore, butyrate salts are known to improve protein and energy digestibility by enhancing gut health (24). In this experiment, hot carcass yields were affected positively by the dietary supplementation of CCB and antioxidants. These results are in line with previous studies stating that supplementation of grape seed byproducts (1, 27), VitE (39), and butyric acid (21, 24) positively affected hot carcass yield in broilers. Relative liver size was found smaller in the groups fed with GSE, GTE, and CCB. Similar results were observed by Biswas and Wakita (6) and Brenes et al. (7). The liver is an important organ for digestive processes. Bile production and relative liver weight correlates with its secretory activity (2). The inhibitory effect of polyphenols on lipid absorption in intestines might negatively affect liver weight (6). However, Vlaicu et al. (34) reported relative liver size of broilers fed with grape seed oil increased in chronic heat stress. Aghazadeh and Taha Yazdi (2) also reported butyric acid supplementation improved liver size in broilers.

In this study, serum biochemical parameters did not change with the dietary supplementation of natural antioxidants with/without CCB. Parallel to our study, similar findings were found for triglyceride $(11,17,30)$, lipoprotein $(11,14)$, and liver enzyme (1) levels. Total cholesterol level was lower in groups fed with natural antioxidant and CCB combination, compared to the control group and those without CCB supplementation, although this low level of cholesterol exists only numerically. Polyphenols and condensed tannins in natural antioxidants are known for their ability to bind cholesterol and prevent the absorption in the intestines (14). Yin et al. (37) also reported that butyric acid affects adipogenesis and lipid metabolism in young broilers and decreases cholesterol content in serum and tissues.

The intestines are an important part of the broiler's gastrointestinal tract and are essential in keeping them healthy and productive (33). Both butyric acid and dietary polyphenols or related phenolic components are used to modulate gut activity $(3,31)$. However, supplementation of natural antioxidants with/without $\mathrm{CCB}$ did not affect jejunum villus height, jejunum crypt depth, jejunum villus height/crypt depth ratio, ileum villus height, and ileum villus height/crypt depth ratio in this study. Also, the ileum crypt depth was adversely altered, especially by the dietary supplementation of GSE and VitE+CCB. Several reports have also documented adverse effects of grape seed products $(13,33)$ and VitE (38) in broilers. Ebrahimzadeh et al. (13) indicated that crypts mainly responsible for the intestinal cell proliferation and lower crypt depth might have a positive effect on the performance of poultry due to decreasing nutrient requirements for intestinal maintenance. Contrary to our findings, previous studies reported that the supplementation of natural antioxidants $(13,17,19)$ and butyric acid salts $(3,24,28)$ had constructive effects on villus height and crypt depth of jejunum in broilers. The discrepancies between the studies might be due to the variety of the dietary feed additive (pomace, extract, powder, microencapsulated, etc), polyphenol content, experimental conditions, and slaughter age.

The TBARS method is commonly used to detect MDA levels, one of the by-products of the lipid peroxidation reaction (29). In this study, the lowest MDA level was recorded in the group fed with VitE. Alphatocopherol is accepted as the most powerful lipid-soluble antioxidant due to the ready donation of hydrogen from the hydroxyl $(-\mathrm{OH})$ group on the ring structure to free radicals $(4,29)$. Other researchers also found similar results to our study in terms of the comparative effects of natural antioxidants. Smet et al. (29) reported that breast meat obtained from broilers fed with $200 \mathrm{mg} / \mathrm{kg}$ alphatocopherol had lower MDA levels than the broilers fed with green tea, grape seed, tomato, or rosemary. Brenes et al. (7) and Goñí et al. (16) also showed that dietary VitE supplementation delayed lipid peroxidation in meat, compared to grape pomace. Likewise, dietary inclusion of alpha-tocopherol showed better antioxidant activity, compared to green tea polyphenol supplementation in growing pigs (4). In agreement with previous studies in broilers $(20,36,40)$, the groups supplemented with CCB also showed significantly low MDA levels in our experiment. Although there are limited data on antioxidant effect of butyrate, it is estimated that butyric acid reduces MDA levels in tissues by suppressing I-kappa-B kinase production and stimulating antioxidant enzymes such as superoxide dismutase and catalase (40). Despite both VitE and $\mathrm{CCB}$ groups having the MDA levels, broilers fed with VitE+CCB showed higher lipid peroxidation in breast meat. Rietjens et al. (25) reported that natural antioxidants may show pro-oxidative effects and increase oxidative stress on tissues in certain conditions or at higher doses. In 
the same study, researchers emphasized that the increasing level of tocopherol radicals could generate lipid peroxidation by themselves.

In conclusion, this study showed that supplementation of natural antioxidants with or without CCB did not impair serum biochemical parameters and intestinal histomorphology in broiler chickens. However, they did have a beneficial effect on hot carcass yield and reducing MDA levels in breast meat. Therefore, a combination of $\mathrm{CCB}$ and natural antioxidants could be used in poultry nutrition to improve carcass performance and to reduce oxidative rancidity to increase the shelf life of meat products.

\section{Acknowledgment}

This manuscript is based on $\mathrm{PhD}$ thesis of Erinç GÜMÜŞ. The authors wish to acknowledge Beypi A.Ş. for chicks and Vimar A.Ş. for grape seed extract, Vitamin E and Sanita Sağlık Ürünleri A.Ş. for coated calcium butyrate supply.

\section{Financial Support}

This research was supported by Ankara University Research Fund (Project No: 16L0238002).

\section{Ethical Statement}

This study was approved by the Ankara University Ethics Committee (2015-18-201).

\section{Conflict of Interest}

The authors declared that there is no conflict of interest.

\section{References}

1. Abu Hafsa SH, Ibrahim SA (2018): Effect of dietary polyphenol-rich grape seed on growth performance, antioxidant capacity and ileal microflora in broiler chicks. J Anim Physiol Anim Nutr, 102, 268-275.

2. Aghazadeh A, Taha Yazdi M (2012): Effect of butyric acid supplementation and whole wheat inclusion on the performance and carcass traits of broilers. S Afr J Anim Sci, 42, 241-248.

3. Antongiovanni M, Buccioni A, Petacchi F, et al (2007): Butyric acid glycerides in the diet of broiler chickens: effects on gut histology and carcass composition. Ital $\mathbf{J}$ Anim Sci, 6, 19-25.

4. Augustin K, Blank R, Boesch-Saadatmandi C, et al (2008): Dietary green tea polyphenols do not affect vitamin E status, antioxidant capacity and meat quality of growing pigs. J Anim Physiol Anim Nutr, 92, 705-711.

5. Bancroft JD, Gamble M (2002): Histological Techniques, $5^{\text {th }}$ edition. 182-189. Churchill \& Livingstone, London, Philadelphia.

6. Biswas AH, Wakita M (2001): Effect of dietary japanese green tea powder supplementation on feed utilization and carcass profiles in broilers. J Poult Sci, 38, 50-57.
7. Brenes A, Viveros A, Goñi I, et al (2010): Effect of grape seed extract on growth performance, protein and polyphenol digestibilities, and antioxidant activity in chickens. Span J Agric Res, 8, 326-333.

8. Calık A, Ceylan A, Ekim B, et al (2017): The effect of intra-amniotic and posthatch dietary synbiotic administration on the performance, intestinal histomorphology, cecal microbial population, and shortchain fatty acid composition of broiler chickens. Poult Sci, 96, 169-183.

9. Carpenter KJ, Clegg KM (1956): The metabolizable energy of poultry feeding stuffs in relation to their chemical composition. J Sci Food Agric, 7, 45-51.

10. Chamba F, Puyalto M, Ortiz A, et al (2014): Effect of partially protected sodium butyrate on performance, digestive organs, intestinal villi and E. coli development in broilers chickens. Int J Poult Sci, 13, 390-396.

11. Chamorro S, Viveros A, Centeno C, et al (2013): Effects of dietary grape seed extract on growth performance, amino acid digestibility and plasma lipids and mineral content in broiler chicks. Animal, 7, 555-561.

12. Dawson B, Trapp RG (2001): Basic \& Clinical Biostatistics, $3^{\text {rd }}$ Edition. Lange Medical Books, McGnawHill Medical Publishing Division, New York.

13. Ebrahimzadeh SK, Navidshad B, Farhoomand $P$, et al (2018): Effects of grape pomace and vitamin $E$ on performance, antioxidant status, immune response, gut morphology and histopathological responses in broiler chickens. S Afr J Anim Sci, 48, 324-336.

14. Farahat M, Abdallah F, Abdel-Hamid T, et al (2016): Effect of supplementing broiler chicken diets with green tea extract on the growth performance, lipid profile, antioxidant status and immune response. Br Poult Sci, 57, 714-722.

15. Farahat MH, Abdallah FM, Ali HA, et al (2017): Effect of dietary supplementation of grape seed extract on the growth performance, lipid profile, antioxidant status and immune response of broiler chickens. Animal, 11, 771-777.

16. Goñi I, Brenes A, Centeno C, et al (2007): Effect of dietary grape pomace and vitamin $E$ on growth performance, nutrient digestibility, and susceptibility to meat lipid oxidation in chickens. Poult Sci, 86, 508-516.

17. Hajati H, Hassanabadi A, Golian AG, et al (2015): The effect of grape seed extract and vitamin $C$ feed supplements carcass characteristics, gut morphology and ileal microflora in broiler chickens exposed to chronic heat stress. Iran J Appl Anim Sci, 5, 155-165.

18. Hassan FA, Mahrose KM, Basyony MM (2014): Influence of grape seeds powder as a natural antioxidant on growth performance, antioxidant status and carass characteristics of rabbits under hot conditions. 395-412. In: The 7th International Conference on Rabbit Production in Hot Climate, Egypt.

19. Hassanpour H, Zamani Moghaddam AK, Yazdani A, et al (2010): Evaluation of intestinal morphology and nitric oxide metabolites in broiler chickens supplemented by green tea. Comp Clin Path, 19, 43-47.

20. Jiang Y, Zhang WH, Gao F, et al (2015): Microencapsulated sodium butyrate attenuates oxidative stress induced by corticosterone exposure and modulates 
apoptosis in intestinal mucosa of broiler chickens. Anim Prod Sci, 55, 587-594.

21. Leeson S, Namkung H, Antongiovanni M, et al (2005): Effect of butyric acid on the performance and carcass yield of broiler chickens. Poult Sci, 84, 1418-1422.

22. Mallo JJ, Puyalto M, Rama Rao SV (2012): Evaluation of the effect of sodium butyrate addition to broilers diet on energy and protein digestibility, productive parameters and size of intestinal villi of animals. Feed Livest, 8, 26-30.

23. National Research Council (1994): Nutrient Requirements of Poultry: $9^{\text {th }}$ Revised Edition, 1994. National Academies Press, Washington.

24. Panda AK, Rao SVR, Raju MVLN, et al (2009): Effect of butyric acid on performance, gastrointestinal tract health and carcass characteristics in broiler chickens. AsianAustralas J Anim Sci, 22, 1026-1031.

25. Rietjens IMCM, Boersma MG, Haan L de, et al (2002): The pro-oxidant chemistry of the natural antioxidants vitamin $C$, vitamin $E$, carotenoids and flavonoids. Environ Toxicol Pharmacol, 11, 321-333.

26. Rowghani E, Tabeidian SA, Abolfathi E (2016): The effects of green tea extract and vitamin $E$ on the growth performance and immune response in broiler chicks. Res Opin Anim Vet Sci, 6, 200-205.

27. Sarıca Ş, Ürkmez D (2016): The use of grape seed-, olive leaf- and pomegranate peel-extracts as alternative natural antimicrobial feed additives in broiler diets. Europ Poult Sci, 80, 1-13.

28. Sayrafi R, Soltanalinejad F, Shahrooz R, et al (2011): Effects of butyric acid glycerides and antibiotic growth promoter on the performance and intestinal histomorphometry of broiler chickens. J Food Agric Environ, 9, 285-288.

29. Smet K, Raes K, Huyghebaert G, et al (2005): Influence of feed enriched with natural antioxidants on the oxidative stability of broiler meat. 99-106. In: Proc. $17^{\text {th }}$ European Symposium on the Quality of Poultry Meat, Doorwerth, Doorwerth, The Netherlands.

30. Taherpour K, Moravej H, Shivazad M, et al (2009): Effects of dietary probiotic, prebiotic and butyric acid glycerides on performance and serum composition in broiler chickens. Afr J Biotechnol, 8, 2329-2334.
31. Van Den Borne JJGC, Heetkamp MJW, Buyse J, et al (2015): Fat coating of Ca butyrate results in extended butyrate release in the gastrointestinal tract of broilers. Livest Sci, 175, 96-100.

32. Villar-Patino G, Diaz-Cruz A, Avila-Gonzalez E, et al (2002): Effects of dietary supplementation with vitamin Cor vitamin $E$ on cardiac lipid peroxidation and growth performance in broilers at risk of developing ascites syndrome. Am J Vet Res, 63, 673-676.

33. Viveros A, Chamorro S, Pizarro M, et al (2011): Effects of dietary polyphenol-rich grape products on intestinal microflora and gut morphology in broiler chicks. Poult Sci, 90, 566-578.

34. Vlaicu PA, Saracila M, Panaite TD, et al (2017): Effect of the dietary grape seeds and rosehip oils given to broilers (14-42 days) reared at $32^{\circ} \mathrm{C}$ on broiler performance, relative weight of carcass cuts and internal organs and balance of gut microflora. Arch Zootech, 20, 77-88.

35. Vossen E, Ntawubizi M, Raes K, et al (2011): Effect of dietary antioxidant supplementation on the oxidative status of plasma in broilers: Dietary antioxidants and oxidative status in broilers. J Anim Physiol Anim Nutr, 95, 198-205.

36. Wu Y, Zhou Y, Lu C, et al (2016): Influence of butyrate loaded clinoptilolite dietary supplementation on growth performance, development of intestine and antioxidant capacity in broiler chickens. PLoS One, 11, e0154410.

37. Yin F, Yu H, Lepp D, et al (2016): Transcriptome analysis reveals regulation of gene expression for lipid catabolism in young broilers by butyrate glycerides. PLoS One, 11, e0160751.

38. Yoo J, Yi YJ, Koo B, et al (2016): Growth performance, intestinal morphology, and meat quality in relation to alpha-lipoic acid associated with vitamin $C$ and $E$ in broiler chickens under tropical conditions. RBZ, 45, 113-120.

39. Zdanowska-Sąsiadek $\dot{Z}$, Michalczuk M, Damaziak K, et al (2016): Effect of vitamin E supplementation on growth performance and chicken meat quality. Europ Poult Sci, 80, $1-14$.

40. Zhang WH, Jiang Y, Zhu QF, et al (2011): Sodium butyrate maintains growth performance by regulating the immune response in broiler chickens. Br Poult Sci, 52, 292301. 